\title{
Isparta Demirci Efe Konağının Mimari Açıdan Analizi ve Yeniden İşlevlendirilmesi
}

\author{
Birsen HAŞTEMOĞLU*, Ş. Gülin BEYHAN \\ Süleyman Demirel Üniversitesi, Mimarlık Fakültesi, Mimarlık Bölümü, 32260, Isparta, Türkiye. \\ *e-mail:hasanhastemoglu@gmail.com \\ Öz \\ Milli Mücadele yıllarında Demirci Mehmet Efe 1920 yılında yedi ay süreyle Isparta ili Gönen ilçesi Iğdecik \\ Köyünde bulunun konakta ikamet etmiştir. Bu binayı karargâh binası olarak kullanmıştır. Bir dönemin tarihine \\ tanıklık etmiş olan konak günümüze değin ayakta kalmayı başarmıştır. Ayrıca konak, tarihi değerinin dışında \\ mimari anlayışı ve gösterişli süslemeleri ile Geleneksel Isparta Evleri içerisinde önemli bir yere sahiptir. Ancak \\ gerek plan kurgusu, gerek yapım sistemi, gerekse bezeme özellikleri ile Batı Anadolu geleneksel konut \\ kültüründen izler taşıyan yapı günümüzde oldukça harap durumdadır. Yapı hem yazınsal literatürde hem de \\ Isparta Mimari Değerleri açısından hak ettiği ilgiyi görememiştir. Çalışma kapsamında, Isparta Kenti açısından \\ mimari ve tarihi açıdan önem arz eden, ancak kırsal yerleşimde bulunması nedeniyle gözden uzak kalan Demirci \\ Mehmet Efe konağı olarak bilinen tarihi yapının mimari açıdan incelenmesi, belgelenmesi ve kentin mimari \\ değerleri arasına kazandırılması için turizm amaçı olarak yeniden işlevlendirilme önerisi getirilmiştir.
}

Anahtar Kelimeler: Demirci Efe, geleneksel konut, Türk evi, yeniden kullanım

\section{Isparta Demirci Efe Mansion Architectural Prespective of Analysis and Re-Functionalisation}

\begin{abstract}
Years of national struggle, Blacksmith Mehmet Efe, has resided in the mansion for seven months in 1920 at Village of Igdecik, Gönen, Isparta. He used this building as a headquarters building. The mansion, which has witnessed a period of history, has managed to stay up to date. The mansion, with its architectural conception and flashy decorations outside their historic value has an important place in traditional Isparta houses. However, the plan shape, making the system even bears traces of the western Anatolian culture and tradition housing decorative features are quite dilapidated condition at the moment. The mansion, both in the literature, did not see the attention that deserves in terms of Isparta architectural value. In this study, The important city in terms of architecture and history, but away from the rest of the eye due to the presence in rural Mehmet Efe mansion has been investigated and examining the architectural, documenting and adaptive re-using for the purpose of tourism between the city's architectural value of the proposal was introduced.
\end{abstract}

Keywords: Demirci Efe, traditional housing, Turkish house, re-use

\section{Giriş}

Geleneksel konutların veya tarihi yapıların turizm amaçlı kullanılmasının yaygın örnekleri mevcuttur. Bu uygulamalarda farklı boyutlarda kazanımlar elde edilmektedir. Çok yönlü bir bakışla; tarihi bir yapıya fonksiyon kazandırıması ile kullanıma açılması yapının korunmasını sağlamaktadır. Yerel ve bölgesel olarak turizmden ekonomik açıdan gelir elde edilmesi sağlanırken, bakımlı kent/yerel/kırsal kimliğe sahip yerleşimler oluşturulur. Turizmin kullanıcısı olan yerli ve yabancı turistinde yapı özelinde seyahat etmiş olduğu destinasyonun tarihi, kültürel, sosyolojik ve etnografik yapısına dair bilgi

Geliş Tarihi: 15/05/2017-Kabul Tarihi:10/11/2017

*Bu çalışma, Süleyman Demirel Üniversitesi Fen Bilimleri Enstitüsünde hazırlanan "Isparta Demirci Efe Konağının Mimari Açıdan Analizı ve Yeniden Işlevlendirilmesi" adlı yüksek lisans tezinin bir özetidir. 
edinmesi sağlanmış olur. Türkiye'nin pek çok yerinde tarihi ve geleneksel yapıların turizm amaçlı kullanımı orta düzeyde ilgi alanı oluşturmaktadır. Safranbolu, Beypazarı, Şirince, Taraklı vb. kırsal/yarı kırsal nitelikteki geleneksel dokusu ile tanınan yörelerde geleneksel konutların restorasyonu ve turizm amaçlı kullanılması ile sürdürülebilir bir turizm konaklama endüstrisine doğru örnekler kazandııımıştır. Çalışma kapsamında da önemli bir kültürel varlık ve mimari miras olarak Demirci Efe Konağı ele alınmıştır. Demirci Efe Konağı yerel hafızada Milli Mücadele dönemini ifade etmesi, mimari ve yerel kimliği ile önem taşımaktadır.

Çalışmanın amacı; Isparta Kenti açısından mimari ve tarihi açıdan önem arz eden, ancak kırsal yerleşimde bulunması nedeniyle gözden uzak kalan Demirci Mehmet Efe konağı olarak bilinen tarihi yapının mimari açıdan incelenmesi, belgelenmesi ve kentin mimari değerleri arasına kazandırılması için turizm amaçlı olarak yeniden işlevlendirme önerisi getirilmesidir.

Milli Mücadele yıllarında Demirci Mehmet Efe 1920 yılında yedi ay süreyle Isparta ili Gönen illçesi İğdecik Köyünde bulunun konakta ikamet etmiş ve bu binayı karargâh binası olarak kullanmıştır (Demirci, 2009a). Bir dönemin tarihine tanıklık etmiş olan konak günümüze değin ayakta kalmayı başarmıştır. Ayrıca konak, tarihi değerinin dışında mimari anlayışı ve gösterişli süslemeleri ile Geleneksel Isparta Evleri içerisinde önemli bir yere sahiptir. Ancak gerek plan kurgusu, gerek yapım sistemi, gerekse bezeme özellikleri ile Batı Anadolu geleneksel konut kültüründen izler taşıyan yapı günümüzde oldukça harap durumdadır. Yapı hem yazınsal literatürde hem de Isparta Mimari Değerleri açısından hak ettiği ilgiyi görememiştir. Çalışma kapsamında, tarihi konak mimari açıdan detaylı biçimde incelenmiş, mimarisinin elverdiği doğrultuda yeniden işlevlendirme projesi hazırlanmıştır.

\section{Demirci Efe Konağı}

Roma İmparatoru Augustos'un 'Psidia' diye anılan yörede (Isparta-Burdur) kurduğu dört şehirden biri olan Gönen, o devirlerde (Comana, Conana, Conan) gibi adlarla anılmıştır. Uzun yıllar Konan ismi ile de anılan Gönen, Konan ismini kervancıların İzmir-Aydın kervan yoluyla iç Anadolu'ya geçerken Gönen höyüğündeki fener nedeniyle, burada konaklamalarından almıştır. Gönen, eski bir medeniyet beşiği olup, tarihi M.Ö. 2000 yıllarına kadar uzandığı tahmin edilmektedir. Ne zaman kurulduğu hakkında, kesin bir tarih tespit edilememiştir. İlçenin kuzeybatısında, 1650m yükseklikte bir tepe üzerinde tarihi bir kale olup, kale hakkında bugüne kadar, hiçbir arkeolojik araştırma yapılmadığından, geniş bir bilgi yoktur. Kale, $4 \mathrm{~m}$ uzunluğunda, $1 \mathrm{~m}$ genişliğinde taşlarla yapılmıştır. Kalenin ihtiyacı olan su Yuvecca yaylasından, $35 \mathrm{~cm}$ çapındaki künk borularla sağlanmıştır. Yine tarih öncesi devirlere ait olduğu sanılan, Gönen Ovası üzerinde bulunan iki tepecikten oluşan höyükler hakkında da, arkeolojik çalışmalar yapılmadığından, kesin bilgiler yoktur. Yapılan araştırmalara göre, ilk yerleşim yeri Yuvecca, şimdiki yayla adıyla bilinen yerdir. Buraya ilk gelenler yöre içi göçerleridir. 0 zamanlar, şimdiki Gönen'in bulunduğu yer ova ve göl halinde olduğu için yerleşim yeri Yuvecca'da gerçekleşmiştir (URL-1).

Selçukluların yıkılış devrinde, Anadolu coğrafyasının birçok yerinde, farklı beylikler ortaya çıkmıştır. Bu yörede ise Hamitoğulları Beyliği kurulmuştur. Zamanla toprakları daralan Hamitoğulları, topraklarının bir bölümünü Osmanlı Padişahı I. Murat'a satmış, Gönen'e çekilerek kalan topraklarını buradan idare etmiştir. Böylece Gönen, büyük ve köklü bir yerleşim yeri özelliği kazanmış, çevresinde 16 köy kurulmuştur. Osmanlı devrindeki kayıtlarda, Gönen için "Hamit İlindeki Gönen” ibaresi yazılıdır (URL1).

Isparta ve çevresi 14. yüzyıldan başlayarak özellikle 19. yüzyılda çok sayıda yerli ve yabancı seyyahın ilgisini çekmiştir. Seyyahların çoğunlukla Afyon-Burdur yolu üzerinden Isparta'ya uğrayarak Antalya'ya ulaştıkları izlenmektedir. Bu seyyahlardan Kâtip Çelebi 1732 tarihli Cihannuma adlı eserinde Isparta çevresinden bahsederken Isparta'nın kazaları arasında Göneni-Hamit'ten de bahseder (Şaman Doğan, 2008). Demirci Efe Konağı bu kurulan 16 köyden birisi olan İğdecik'de bulunmaktadır. 

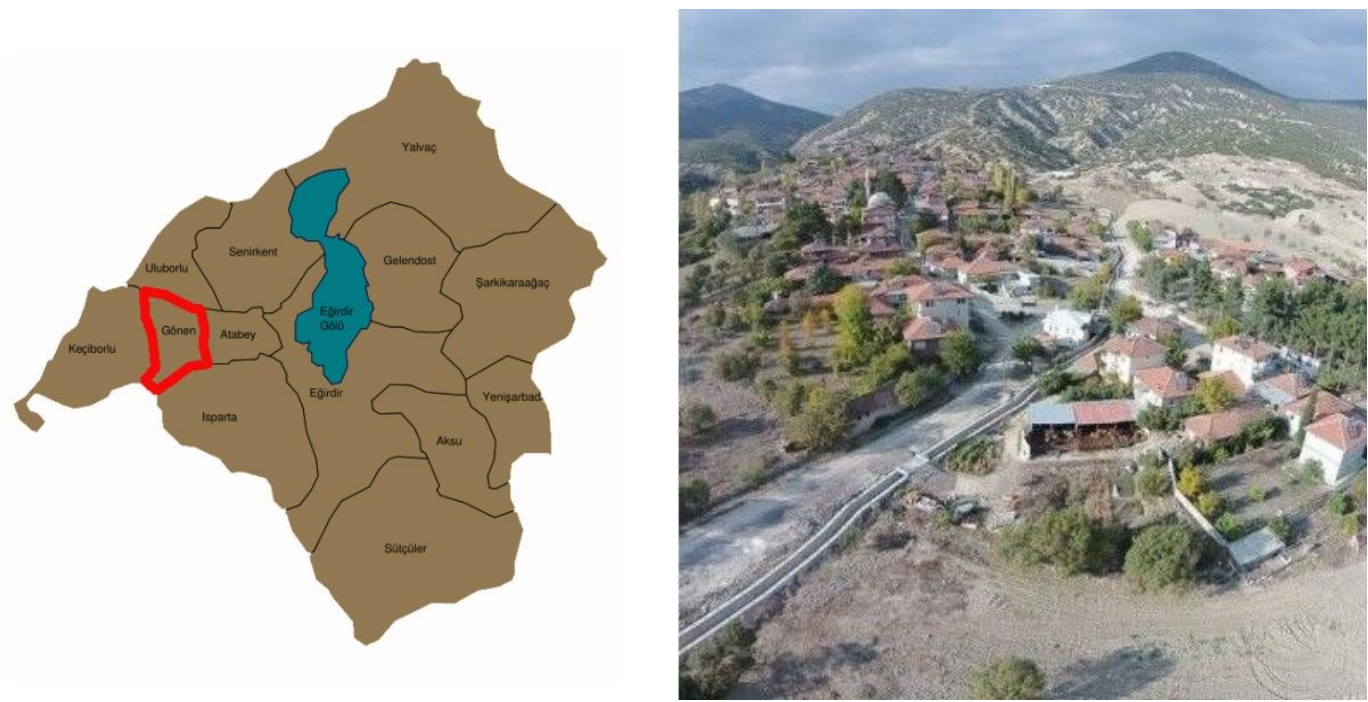

Şekil 1. Isparta Kenti Gönen İlçesi ve Isparta / Gönen / İğdecik Köyü genel görünümü (URL-2).

On altıncı yüzyılda İğdecik köyü Gönen ovasında, içinde, 35 evden oluşan küçük bir yerleşimdir. On sekizinci yüzyılın başında terk edilen köy 1747 yılında Çelik Paşa himayesi altında yeniden kurulmuştur. Köy on sekizinci yüzyılda yeniden yükselişe geçmiştir (De Planhol, 1958). Genel olarak Gönen tarihi Isparta tarihiyle paralellik gösterir. Konut üretiminde de benzerlikler dikkat çeker. Dönemin Türk aile yapısına uygun olarak her evde ortalama 4-5 oda mevcut olup, her birinde bugünkü anlamda bir aile barınmaktadır. Her oda musandıra adı verilen banyosu, mutfak için kullanılan ocağı ile beraber aynı zamanda oturma ve yatak odasıdır. Avluların yanlarında hayvanlar için yapılmış yerler bulunur. Ancak bu konut dokusunu oluşturan sivil mimarlık örneği ahşap evlerin çoğu günümüze değin yangınlar ve zamanın etkisiyle yok olmuştur. Birçoğu ise harap durumdadır. Büyük çoğunluğu bakımsızlık, terk, bayındırlık etkinlikleri, rant baskısı gibi çeşitli tehlikelerle karşı karşıyadır. Özensiz yapılaşma ve hatalı uygulamalar nedeniyle geleneksel doku zarar görmüş ölçek ve özelliklerini yitirmiştir.

Demirci Efe Konağı da bu tür nedenlerle kullanılamaz hale gelmiştir. Araştırmaya konu olan konak, Milli Mücadele yıllarında Demirci Mehmet Efe'nin 1920 yılında yedi ay süreyle ikamet ettiği ikametgâhı ve karargâhı olarak kullanılan tarihi öneme sahip bir evdir. Demirci Mehmet Efe, Milli Mücadele tarihinde İğdecik Baskını olarak bilinen tarihi olayda, bu konakta bulunmaktaydı. Baskın sabahı bu konaktan kaçarak İğdecik Köyü'nün arkasındaki dağlara sığınmıştır. İ̆decik Köyü’nde bulunan ve bir dönemin tarihine tanıklık etmiş olan konağın yapım tarihi belli olmayan, 19. Yüzyıl sivil mimari örneği olduğu tahmin edilen yapının tam yapım tarihi bilinmemektedir (Demirci, 2009a). Çünkü geleneksel evlerinde çoğu zaman inşa tarihini veren bir kitabe veya tarih kaydı bulunmaz. Az sayıda örneğin içinde ya da cephesinde sadece tarihle ilgili görünen bir sayıya rastlanır (Uysal, 2012).

"Ev" Türkçede konut için kullanılan en yaygın addır. Geleneksel Türk evi yurttan konağa kadar uzun bir evrim geçirmiştir. Hayatlı Türk evi Anadolu'ya özgü ve çok özgün bir konut tipidir, ancak kesinlikle kırsal bir yaşamı yansıtır. Bu evrimin sonucunda ortaya çıkan konak, sıradan bir evden çok daha büyüktür ama önceli olan ev tipleriyle aynı mimari öğeler sözlüğünü paylaşır. Konak sıradan evlerden ya olağan üstü boyutları, ya sahibinin sosyal konumu ya da özel mimari nitelikleri ve süslemeleriyle ayrılır (Altıner ve Budak, 1997). Bu nedenle çalışma konusu yapıya konak denmesi uygun olacaktır.

\section{Demirci Efe Konağı Mimari Analizi}

Yapı genel olarak çok önemli mekânsal değişikliklere uğramadan günümüze kadar gelebilmiştir. Bölgede az sayıdaki kalan geleneksel konutlardan biridir. Yapıda günümüze değin hiçbir kapsamlı onarım ve restorasyon çalışması yapılmamıştır. Ancak zaman içerisinde yapı sahipleri tarafından farklı zamanlarda lokal onarımlar, yenileme çalışmaları ve mekan eklemeleri yapılmıştır. Yapının sağ yan cephesine eklenen niteliksiz derme çatma mekânlar ise yapı algısına zarar vermektedir. Ancak bu ekler yapının özgün cephe kimliğine çok fazla müdahale etmemiştir. Yapıya bu eklerden daha fazla zarar veren, cephe ve çatıda meydana gelen su deformasyonları olmuştur. 


\section{1. Bodrum kat analizi}

Yapının bodrum katı hanay, tahıl ambarı ve iki adet depo mekânından oluşur. Hanay bodrum katta yapının güney cephesinde yer alan mekândır. Güney cephesi tamamen açıktır, Taşıyıcı ahşap sütunlar işlemeli mermer ayaklara oturmaktadır. Şekil 2'de görüldüğü biçimde Mekânın güney doğu köşesinde üst kata ulaşımı sağlayan sahanlıklı bir ahşap merdiven bulunmaktadır.

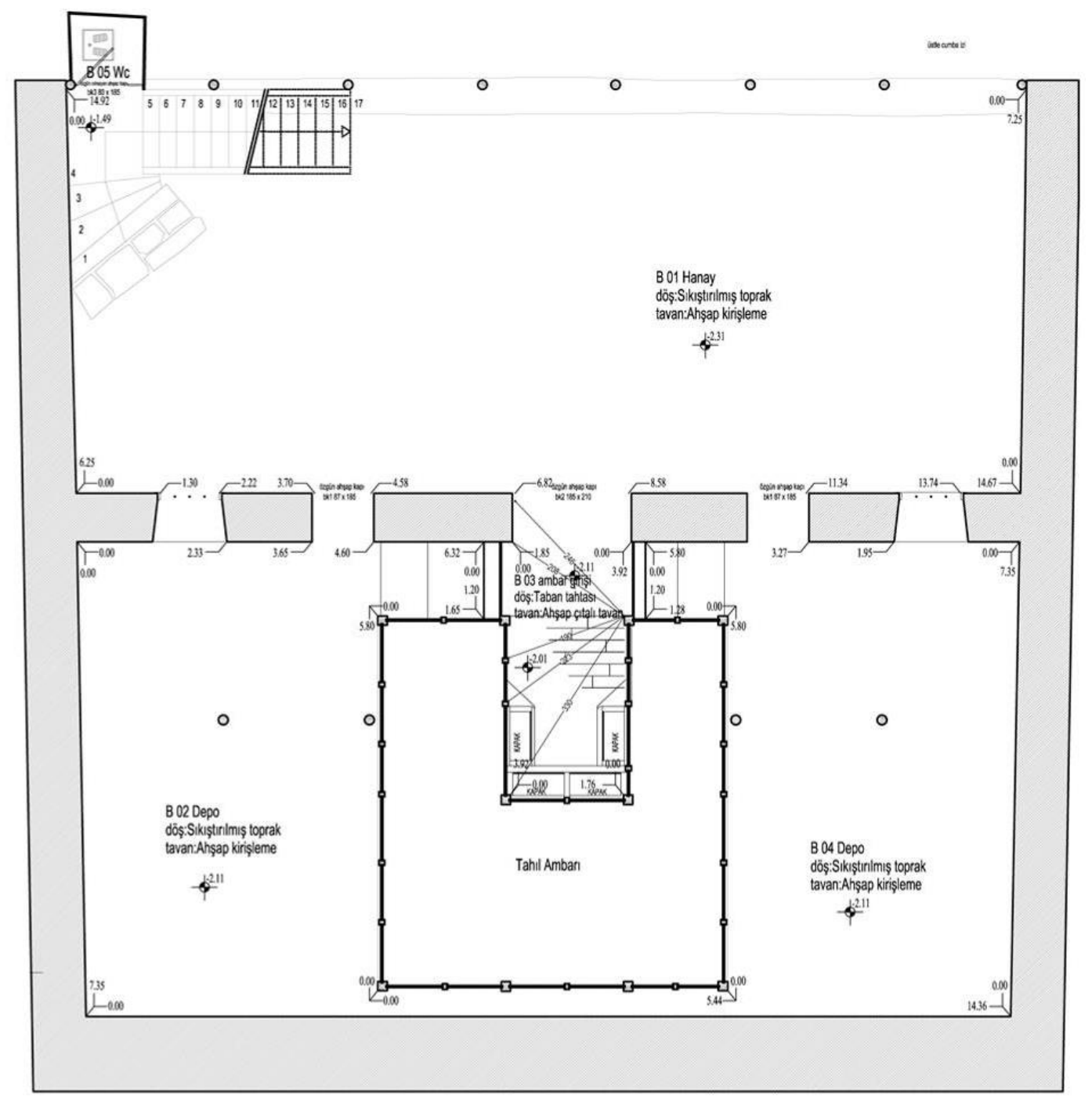

Şekil 2. Bodrum kat planı

Mekânın sütunlu güney cephesi dışında üç tarafı ahşap hatıllı moloz taş duvar ile çevrilidir. Hiç pencere bulunmayan mekânda bodrum kattan zemin kata çıkan merdivenin bitiş noktasında döşemeye paralel şekilde inşa edilen ahşap kayar kapı dikkat çeker. Bodrum katta bulunan günümüzde depo olarak kullanılan iki mekânın geçmişte ahır olarak kullanılmış olması muhtemeldir. Bodrum kat mekânlarında tavanlar ahşap kirişlemedir. Mekânların doğal taş kaplama olan döşemeleri sökülmüş ve geriye sadece sıkıştırılmış toprak kalmıştır. Bodrum katta doğu cephede yer alan ambar girişi bodrum katta yapının tam merkezinde bulunan, tahıl ambarında depolanan mahsule ulaşmak için oluşturulmuş bir mekândır. İçerisinde tahıl ambarından tahıl almak için kullanılan dört adet kapak bulundurmaktadır. Mekânın duvarları aynı zamanda ambarın da duvarı olup ahşap dikmelerin arasında geçirilmiş $3 \mathrm{~cm}$ kalınlığında ahşap latalardan oluşmaktadır. Sonuç olarak yapının bodrum katında günümüze değin önemli bir yapısal değişiklik yaşanmamıştır. Geçmişte olduğu gibi günümüzde de hanay-depo işlevleri devam etmektedir. 


\subsection{Zemin kat analizi}

Yapının zemin katı kuzey güney doğrultusunda bulunan T formundaki sofanın iki yanına yerleştirilmiş dört adet oda ve iki adet kiler mekânından oluşur. Dört odadan giriş cephesinde yer alan ikisinde pencerelerin arasında bulunana iki adet gömme dolap haricinde birer adet çift kanatlı ahşap dolap ve bir adet şerbetlik bulunmaktadır. Bu özgün mimari elemanlardan kapılar oldukça zengin ahşap oyma işçiliği ile göze çarparken, şerbetliklerin özenli alçı işçiliği ayrıca dikkat çeker. Bunların yanında mekânlarda cephe duvarında ahşap sedir bulunur. Diğer iki odada ayrıca ocaklar bulunur. Odalar geleneksel ahşap çıtalı tavanları oldukça sade inşa edilmiştir. Bu dört odanın arasında bulunan kiler mekânlarında ise özgün ahşap işlemeli kapılar dışında önemli bir detaya rastlanmaz.

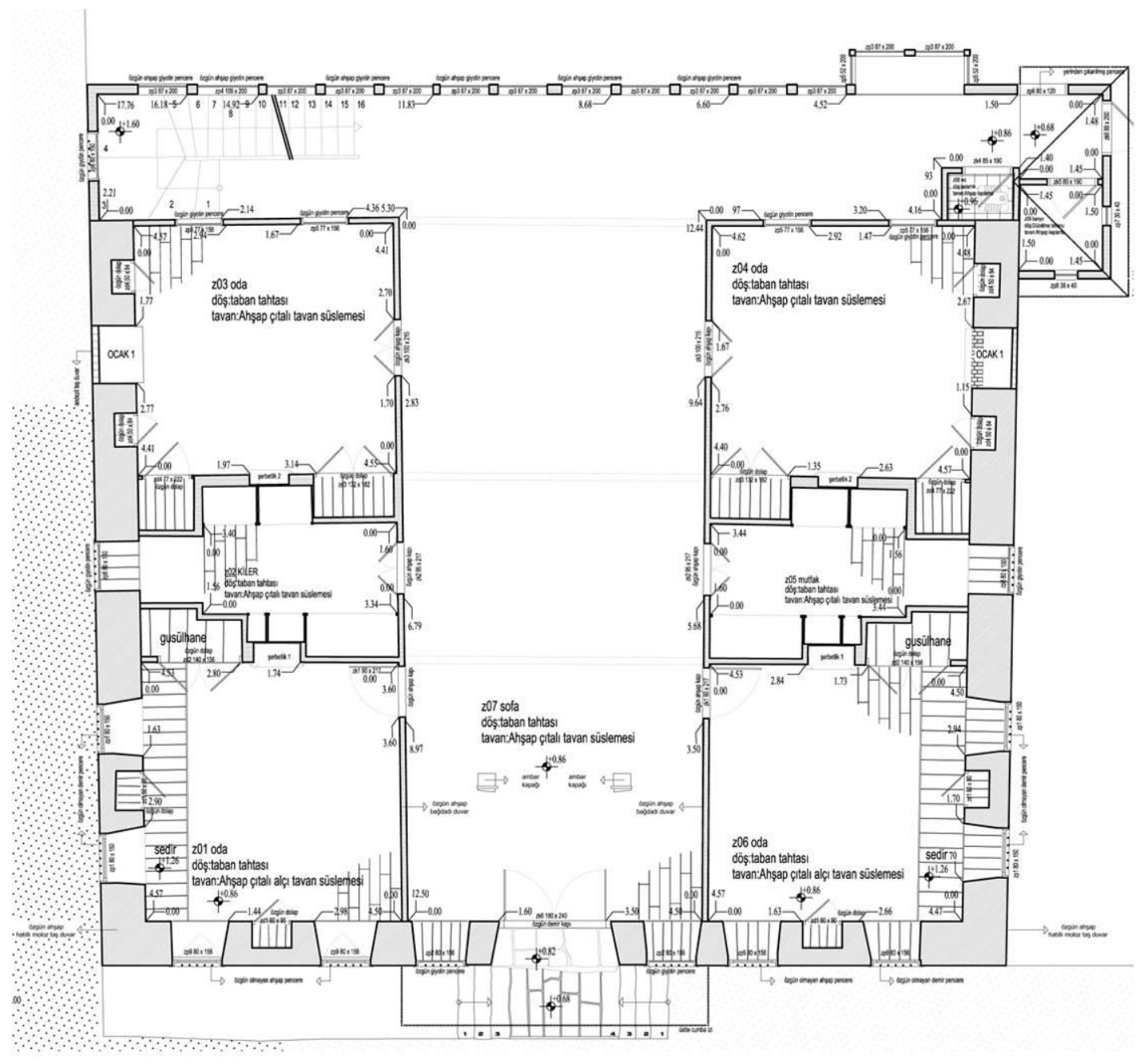

Şekil 3. Zemin kat planı

Sofa mekânı ise zemin katta yapının tam ortasında simetri aksı oluşturan ' $T$ ' formundaki mekândır. Mekâna dar kenarından işlemeli bir demir kapıyla sokaktan ulaşılmaktadır. Mekânın güney cephesine ' $T$ ' formun geniş kenarına güneşten maksimum düzeyde faydalanmak amacıyla tamamen pencere yapılmıştır. Sofanın doğu köşesinde yer alan ahşap merdivenden hem bodrum kat hanaya hem de 1. kat sofa mekânlarına ulaşııı. Batı köşesindeki ıslak hacimler yapıya sonradan eklenmiştir.

\subsection{Birinci kat analizi}

Yapının birinci katında zemin kata benzer şekilde kuzey güney doğrultusunda bulunan T formundaki sofanın iki tarafına yerleştirilen dört adet oda bulunur. Ancak zemin katta odalar arasında bulunan kiler mekânları iptal edilmiş sofa kısmı büyütülmüştür. Birinci katta yer alan dört odanın tamamı "baş oda denilebilecek mimari detaylara sahiptir. Zemin katın aksine tüm ahşap kapı ve dolap kapakları işlemelidir. Giriş cephesinde iki odada tavanları ahşap çıtalı alçı tavan süslemelidir. Tavanlarda özgün ahşap ve alçı işçiliği göze çarpar. Diğer iki odada ise elips formu ışınsal ahşap çıtalı tavan süslemesi bulunur. Sofanın güney cephesinde iki köşede bulunan köşkler ve sofanın kuzey cephesinde ise giriş 
kapısının üzerinde sokağa doğru çıkma yapan bölüm sedirlerle donatılmıştır. Sonuç olarak yapının birinci katında günümüze kadar önemli bir mekânsal değişiklik olmamıştır.

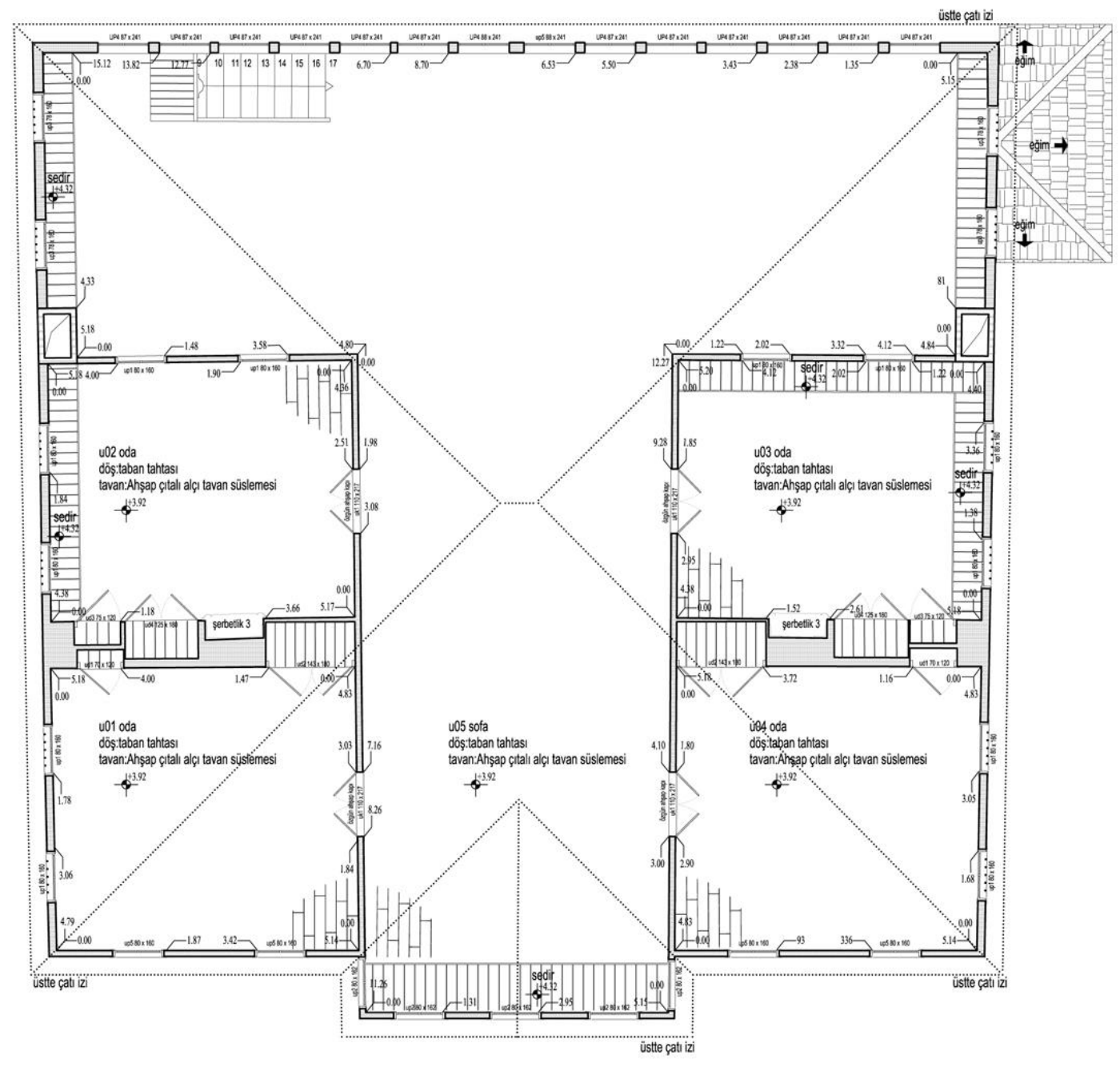

Şekil 4. Birinci kat planı

\subsection{Demirci Efe Konağı yapısal sistemi}

Demirci Efe konağı doğal topografyayı kullanarak bodrum katın güney cephesini açıkta bırakan, yol kotundan bakıldığında zemin üzeri bir kat olarak algılanan, kareye yakın planlı, geleneksel yapım sistemleri kullanılarak inşa edilmiş bir yapıdır. Bodrum katın güney cephesi dışında tüm beden duvarları, yöresel taşların kullanıldığı, genişliği yer yer $1 \mathrm{~m}^{\prime}$ ye ulaşan ahşap hatıllı moloz taş duvardır. Duvarların üzeri sıvasızdır. Güney cephede ise yapı çevre ören yerlerinden toplandığı düşünülen devşirme sütun ayakları üzerine oturtulmuş altı adet ahşap direk ile taşınmaktadır. Dış beden duvarlarından daha ince olmakla birlikte $(75 \mathrm{~cm})$, ahır-depo kısmını meydana getiren iç mekân duvarları da ahşap hatıllı moloz taş duvardır. Zemin kat döşemesini de oluşturan bodrum kat tavanı, $25-30 \mathrm{~cm}$ çapında ahşap kirişler üzerine $10-15 \mathrm{~cm}$ çapında ahşap elemanların zıt yönlü olarak çakılmasıyla oluşturulan döşeme üzerine $2-3 \mathrm{~cm}$ kalınlığında döşeme tahtası çakılmasıyla meydana getirilmiştir. Bodrum kat tavanı kaplamasızdır. 0.00 Yol kotundan $-2.20 \mathrm{~m}$ seviyesine ulaşan bodrum kat zemininin, yapıdaki izlerden ve kalan kısmi bölgelerden, geçmişte doğal taş kaplama olduğu düşünülse de günümüzde sıkıştırılmış topraktır. 


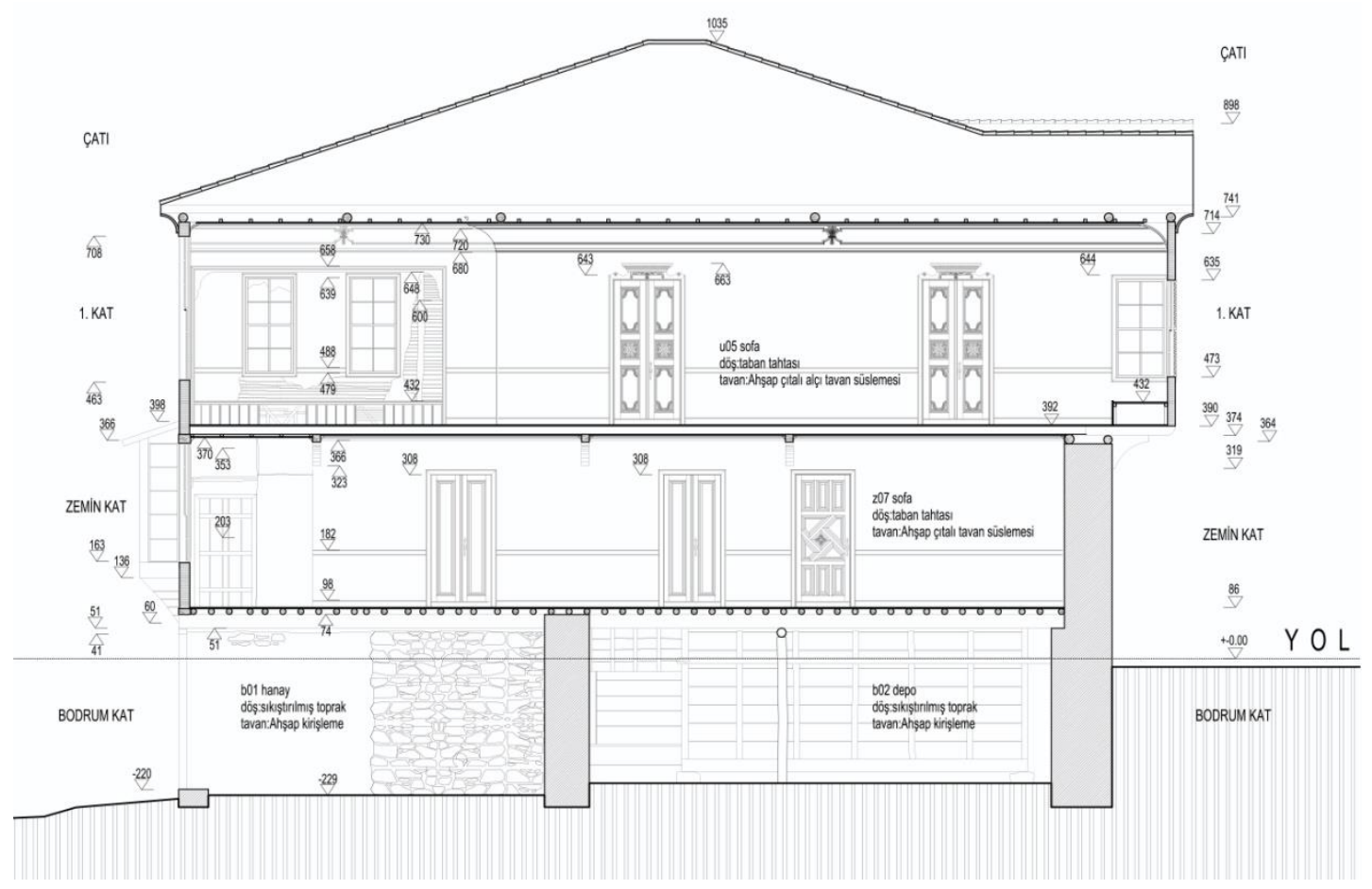

Şekil 5. Yapının kuzey-güney doğrultusunda kesiti

Güney cephede bodrum kattan ahşap merdivenle veya kuzey-yol cephesinde cümle kapısıyla ulaşılan zemin katın da bodrum kata benzer şeklide manzaraya bakan güney cephesi dışında tüm duvarları ahşap hatıllı moloz taş duvardır. Taş duvar kalınlığı ortalama $75 \mathrm{~cm}$ 'dir. Ancak ocakların bulunduğu yerlerde duvarı incelterek ocakları duvar içerisine yerleştirebilmek için ocak sırtlarında $15-20 \mathrm{~cm}$ kalınlığında kövke taşından kesme taş duvar uygulaması yapılmıştır. Yapının zemin kat duvarları içten sıvalı dıştan sıvasızdır. Dış duvarların sıvasız oluşu derzlerde meydana gelen güneş ve su deformasyonunu büyük ölçüde artırmıştır. Yapının güney cephesi tamamen ahşap doğramadan camekân olarak inşa edilmiştir. Zemin kat tavanı ahşap kirişleme üzeri çıtakari tavan kaplamasıdır. Güney cephede yer alan ahşap bir merdivenle ulaşılan 1. katın güney cepheyi oluşturan ahşap doğrama camekân cephesi dışında tüm duvarları ahşap taşıyıcı üzeri 2-3 cm ahşap iskiyet çakılarak üzeri kıtıklı sıva ile sıvanan bağdadi duvarlardan oluşur. Ancak dış cephede kesme taş duvar görüntüsü verilerek uygulanan dış sıvanın büyük bölümü günümüzde doğa koşulları nedeniyle dökülerek kaybolmuştur. 1 kat tavan döşemesi konveks kornişli çıtakari işlemelidir. Ahşap oturtma çatı üzeri kiremit kaplıdır. Yapının bacalarında metal kenetli kövke taşı kullanılmıştır.

\subsection{Demirci Efe Konağı cephe düzenlemesi}

Demirci Efe konağının yapının an girişinin bulunduğu kuzey cephesi, plan şemasını yansıtır biçimde giriş aksına göre tam simetrik bir düzene sahiptir. Giriş kapısı üzerine markiz etkisi yapan 1. kat sofa çıkması yapının yegâne cephe hareketidir. Üzeri üçgen alınlıklıdır. Giriş kısmının üzeri Bursa tipi kemerlidir. Zemin kat moloz taş duvarını desteklemek amacıyla 40-50 cm. aralıklarla ahşap hatıllar kullanılmıştır (Demirci, 2009b). 1. kat üzeri kesme taş görünümlü kıtık sıvalı ahşap bağdadi duvardır. Cephede hem zemin hem birinci katta $1 / 2$ oranlı giyotin pencereler kullanılmıştır. Zemin kat demir ferforjeli 1. kat ahşap kepenklidir. 

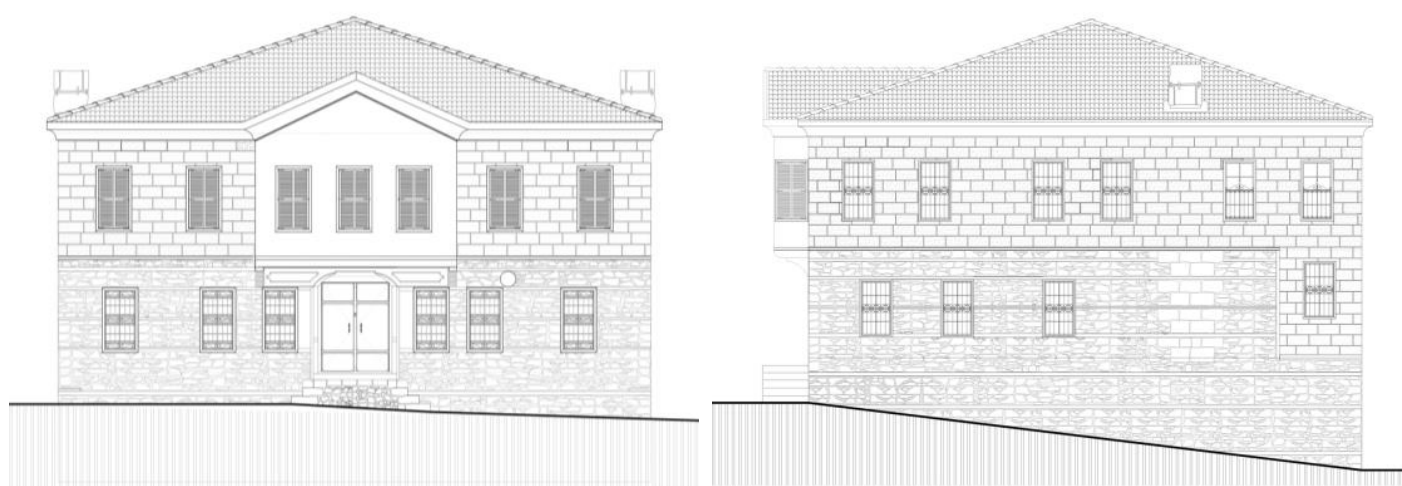

Şekil 6. Kuzey-giriş cephesi ve Batı cephesi
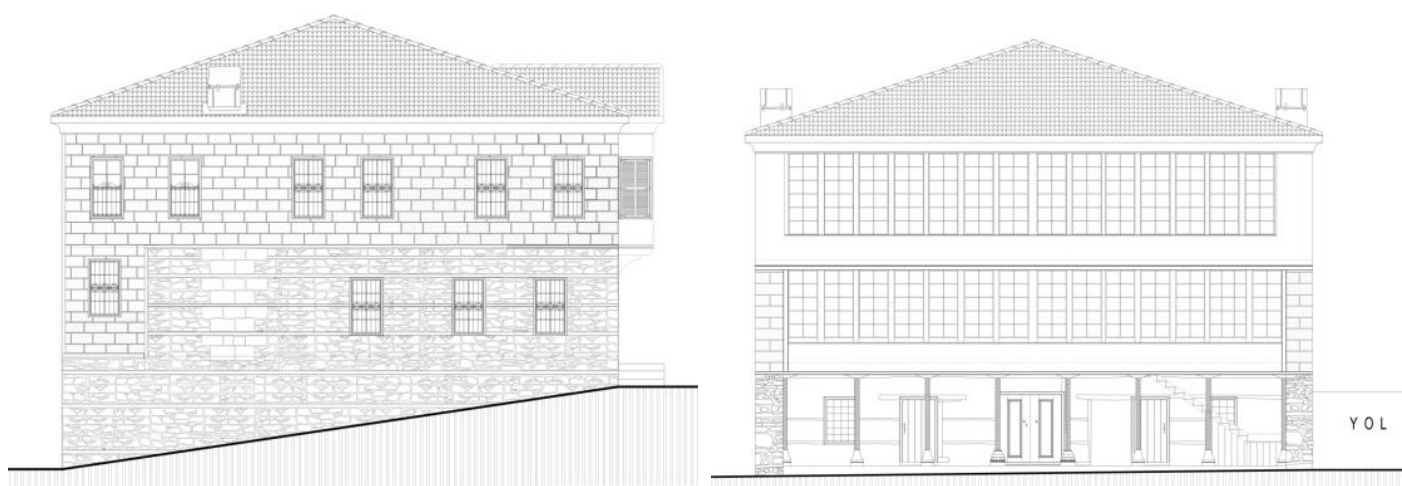

Şekil 7. Doğu cephesi ve Güney cephesi

Yapının Batı cephesi ve Doğu cephesi, yapının kuzey güney doğrultusundaki simetrik plan şeması nedeniyle aynıdır. Yapının geneline uygun biçimde zemin kat sıvasız, 1.kat kesme taş görünümlü sıvalıdır. Moloz taş duvarlarda ocakların arkasındaki kövke kesme taş duvarlar görülür. Kuzey cephesi aksine 1. kat pencereleri de ahşap kepenkli değil demir ferforjelidir. Ovaya hâkim manzara yönünü oluşturan güney cephe ise 6 adet ahşap dikme ile taşınan hem zemin hem de 1. katta güneşten en iyi şekilde yararlanmak amacıyla tamamen camekân yapılmış oldukça basit bir forma sahiptir. Doğramanın altında kalan bağdadi kısımlar kıtık sıva ile sıvanmıştır. Yapının tam simetrik yapısı bu cephede de kendini gösterir.
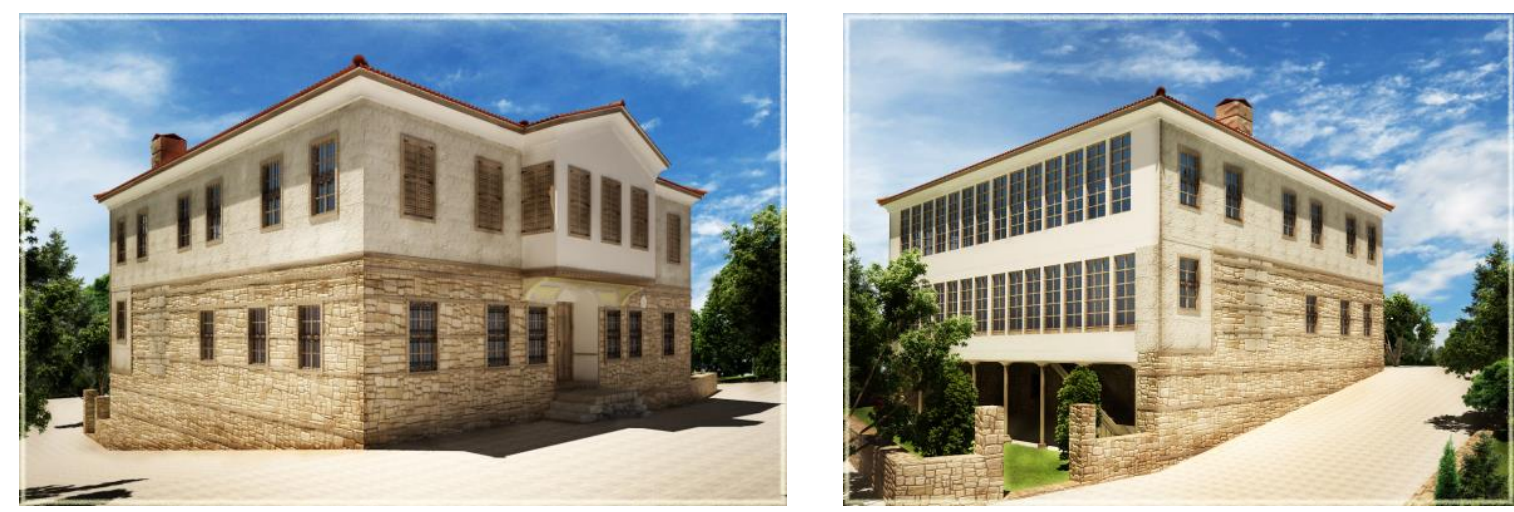

Şekil 8. Cephe restitüsyon çalışması

\section{Demirci Efe Konağı Yeniden İşlevlendirme Önerisi}

Çalışmada Şekil 9'da gösterilen işlem sırası ile Demirci Efe konağının yeniden işlevlendirme önerisi hazırlanmaya çalışılısıstır. Bu aşamada konak için uygun olduğu düşünülen Butik Otel işlevinin güçlü ve zayıf yönleri incelenmiş, ihtiyaç duyulan mekânların konağa uygunluğu sorgulanmıştır. 


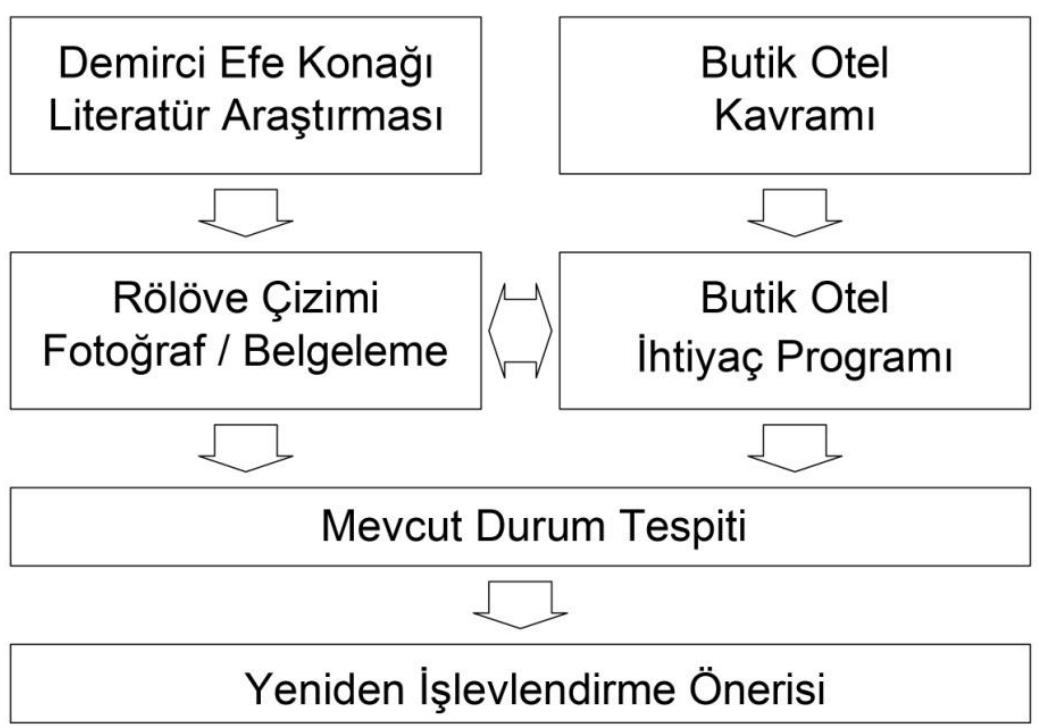

Şekil 9. Demirci Efe konağını yeniden işlevlendirme süreci

Türkiye'de kırsal alan koruma kavramı, yurt dışı örneklerine göre oldukça yeni bir kavramdır. Ulusal mirasın korunması işlevinin yanı sıra yerel kültürün sürekliliğini sağlayan ve toplumlara ait gelenek ve görenekleri günümüze taşıyan alanlar olmaları sebebiyle kırsal alanların korunması son derece önemlidir. Kırsal alanlarda en önemli işlevler barınma ve üretimdir. Bu sebeple de barınma işlevinin gerçekleştirildiği "konut" önem kazanmaktadır. Kırsal konutların biçimlenmesinde yerel kültür, gelenek, örf ve adetlerin yanı sıra yaşam koşulları (ekonomik yapı, doğal yapı vd.) da etkin olmaktadır. Bu konutlar, geleneksel dokuyu ve yerel kültürü yaratan ve yaşatan yapılar oldukları için, kültürel ve mimari mirasın gelecek nesillere aktarılmasında etkili araçlardır. Geleneksel konut dokusunun korunması, yaşatılması ve geleceğe aktarılmasında turizm etkin bir sektördür. Bu anlamda turizm sektörü, eğer doğru biçimde kullanılan bir araç olarak koruma sürecine katılırsa istenilen sürdürülebilirlik elde edilmiş olur. Sektörün getireceği ekonomik fayda (yeni iş imkânları, yeni ekonomik gelir alanları vb. şekillerde) korumayı sağlamanın yanı sıra bölge için bir kalkınma aracı da olacaktır (Gürer, 2003).

Ancak kültür ve tarih birikimi olan bu eserlerin; korunarak onarımı ve kullanımı esastır. Turizmde yeni bir kavram olan butik otel; geleneksel Türk evinin otele dönüşümünde tasarım ve fonksiyon öğelerinin çakıştırılmasında uyum göstermektedir. Bu konu değerlendirilirken turizmin kitlesel yaklaşımından kaçınılmalıdır. Bu yaklaşım Türk evinin orijinal değer ve özelliklerine zarar verebilir. Geleneksel Türk evinin butik otele dönüşümü sırasında ve sonrasında koruma, yerellik ve sürdürülebilirlik öğeleri değerlendirilmeli ve sağlanmalıdır.

Konaklama tesislerinde kimlik adeta bir program girdisi gibi yapının Pazar değerini, işletme verimliliğini etkileyen bir unsur olarak öne çıkmaktadır. Yapının anlamsal dışavurumu, doğrudan çekiciliğini, farklılığını ve tüketim objesi olarak Pazar değerini etkileyen bir unsur olarak meşruiyet kazanmaktadır. Butik otel kavramı dünyada giderek yayılan turizm işletmeciliği uygulamalarındandır. Bu otel tiplerinin yaygınlaşmasının ardında, müşterinin şıklık ve konforu bir arada bulabilmesi, yüksek kalitede kişiye özel hizmet sunularak müşterilerin kendilerini evinde hissetmelerinin sağlanmaya çalışılması ve az sayıda oda kapasitesine sahip olmasına rağmen üst gelir gruplarından turistleri çekebilmesinin bir sonucu olarak yüksek gelir elde edilebilmesi gibi sebepler yatmaktadır (Yüksel, 2009).

Bu yaklaşımlar bağlamında çalışmada Demirci Efe konağı olarak bilinen tarihi yapının butik otel olarak yeniden işlevlendirilmesi önerilmiştir. Ancak incelenen örnek projeler, taranan literatür kaynaklar ve öneri proje hazırlanma süreci sonucunda Türkiye'de Türk Evi olarak adlandırılan geleneksel konutların konaklama amaçlı olarak Butik Otel'e dönüştürülmesi sürecinde mimari bağlamda yaşanan sorunların üç temel grupta toplandığı söylenebilir. Bunlar şunlardır. 
Oda sayısına ve düzenlenmesine yönelik sorunlar;

Özellikle Safranbolu gibi turistik bölgelerde konaklar kitle turizminin aşırı baskısı altındadır. Restorasyon aşamasında hemen hemen tüm tarihi yapılara, ek yatak kapasitesi yaratacak şekilde yeni odalar eklenmekte, bu durum konağın plan şemasına büyük ölçüde zarar vermektedir (Yüksel, 2009). Demirci Efe konağında on adet oda bulunması bu sorunun yaşanmasını engellemiş olsa da, butik otel yönetmeliğinde yer alan en az oda ibaresi ve işletmecilerin daha fazla oda talebi içerisinde olması geleneksel konutların butik otele dönüştürülmesinde ciddi bir sorun olarak karşımıza çıkmaktadır. Diğer taraftan geleneksel konutlarda odalar gündüz yaşama gece yatma mekânına dönüşmektedir. Ancak bu çok fonksiyonlu durum standart otel yatma üniteleri için uygun değildir. Öyle ki geleneksel yaşama kültürümüzün bir ürünü olan mimari ile bütünleşmiş birkaç eşyadan oluşan odaların görünümünü, bu kültüre yabancı yatak, gardırop, iskemle ve benzer elemanlarla bozmadan, buna karşılık geceleme gereksinimine de yeterli ölçüde cevap verebilecek biçimde çözme yoluna gidilmesi gerekmektedir (Yüksel, 2009).

Incelenen örnek projelerde genellikle sedirler oturma ve yatma işlevlerinin yanında yatak ucu sehpası olarak kullanılmaktadır. Bu çözümlerde odalarda bulunması gereken mobilya sayısı en aza indirilirken, özgün parçaları ve yenilenen kısımlarıyla dolaplar dikkat çekmektedir. Oda sedirlerini olduğu gibi kabul eden yatak çözümleri, yatakların ayak taraflarında bulunan gezer bazalar kaydırılarak gerektiğinde yatakların birleştirilebilmesine olanak tanımaktadır (Canbulat, 2012). Odalarda bulunan ocak bölümleri ise restore edildikten sonra yatak odalarının mekânsal kalitesine büyük katkı sağlamaktadır.

Islak hacimler ve tesisat sorunları;

Bugünün konfor şartları ve yönetmelikler oda birimi içinde duş-wc kullanımını gerektirmektedir. Butik otele çevrilen konaklarda ıslak hacimlerde genellikle banyo tuvalet grupları, özgün ahşap döşeme üzerine dökülen bir betonarme döşeme ve duvarlara kaplanan fayanslarla çözüle gelmektedir. Ancak ahşap iskelet taşıyıcılarla oluşan konaklar sürekli hareket halindedir. Bu nedenle zaman içinde fayans kaplı yüzeylerde ve köşelerde çatlama olması kaçınılmazdır. Öte yandan beton ve diğer toprak malzemenin ısı geçirgenliğinin ahşaptan farklı olması beton yüzeylerde çiğlenmeye, gözenekli yapısı ise sürekli rutubetli kalmalarına neden olmakta ve çevrelerinde ahşap zararlılarının yaşaması için uygun habitatlar oluşturmaktadır. Mevcut çözümlerde yüklük fonksiyonu gusülhanenin bulunduğu yerden kaldırılıp, yalnız lavabo ve duş eklenerek çözülebilirken, giderlerin bağlanması ve atık suyun atılması sorunları çözülmüşse oda içindeki gusülhane birimine klozet de eklenebilmektedir. Aksi takdirde abdestlik ortak kullanım için (geleneksel kullanımda olduğu gibi) kullanılmaya devam edebilir. Bir başka tercih de hazır banyo kabinleri kullanmak olacaktır. Kabinlerin içinde çözülecek bütün detaylar kabin dışında yalnızca tesisat bağlantıları ile binaya bağlanacaktır. Böylece ıslak hacimlerin binaya vereceği su, nem, tesisat müdahaleleri en aza indirilecektir. Eskiyen banyo kabinleri çıkarılıp, başka bir kabinle değiştirilebilecektir. O halde hazır banyo kabini kullanılarak mevcut binaya müdahaleyi azaltmak ve suyun ve buharın binaya vereceği zararı azaltmakta önemli olacaktır (Yüksel, 2009).

Bunların dışında örneklerde ada küvetli banyo çözümleri görülebilmektedir. Lavabo ve klozetlerin panolarla gizlendiği bu çözümlerde konağın döşemesine oturtulan bölücü, taşıyıcı ve donatı sağlayan panolar sökülebilecek şekilde tasarlanmaktadır (Canbulat,2012).

Demirci Efe konağında odalarda yer alan ıslak hacim sorunları, zemin katta sofa içine taşan mekânlarda rüzgârlık eklenerek, mevcut dolap ve gusülhaneler genişletilerek veya geniş taş duvarlara gömülmek suretiyle oluşturulmasıyla aşılmaya çalışılmıştır. Bu mekânların dış cepheden havalandırılmasına ve düşeyde tesisat birliği oluşturulmasına dikkat edilmiştir. Bu yolla en az müdahale ile en fazla fayda sağlama düşüncesi ön planda tutularak minimal ölçülerde dolap kapakları arkasına gizlenen çözümler tasarlanmıştır.

Ortak mekânların düzenlenmesi sorunları;

Hayat butik otel kullanımında lobi, karşılama mekânı olarak kullanıma uygundur. Kazan ocağı mekânı ise yemeklerin burada hazırlanıp, servis edilmesine uygundur. Ambar ve samanlık mutfağa yakınlığı 
itibariyle günümüzdeki kullanımıyla kiler olarak (ambar; kuru baklagiller, samanlık; diğer erzakların depolanmasında) kullanılabilir. Ahır, butik otel kullanımında kazan ocağına yakınlığı itibariyle restoran olarak veya mutfak olarak kullanılıp kazan ocağı mekânı restoran ve servislerin gerçekleştirilmesinde kullanılabilir. Günümüz otel mekânında insanların toplanıp, eğlendikleri, sohbet ettikleri, düŭün, kutlama gibi eylemleri gerçekleştirdikleri mekânlar giriş katında lobi ya da restoran gibi mekânlarda gerçekleşir. Butik otel için eski Türk evi kullanımının sentezi; sofa mekânının ortak alan olarak kullanımı olarak gerçekleşir. Ortak kullanım alanlarından sofalara dağılabilir. Bunun sakıncası oluşacak gürültünün yatak odalarını rahatsız etmesidir. Geleneksel konakların restorasyonunda bir sorun da zemin katlarda yer alan ortak kullanım mekânlarıdır. Bu sorun turizm amaçlı olarak kullanılan tüm konakların ortak sorunudur. Hemen hemen tüm işletmeciler, daha büyük ve aydınlık ortak kullanım mekânları istemektedir. Buna karşın kalın taş duvarlarla belirlenen zemin katlar ise işlevleri farklı (at ahırı, mal ahırı, hazine, vb.) çeşitli mekânlara bölünmüştür (Yüksel, 2009). Bu nedenle bazı mekânların birleştirilmesi gerekir ancak bu durum bir taraftan yapının plan şemasına zarar verirken diğer taraftan kaldırılan taşıyıcı duvarlar yerine modern malzeme kullanılan çözümler gerektirir.

Bu ortak mekân sorunlarından sofaların lobi ve oturma salonu gibi mekânlar için kullanılmasının yarattığı gürültü sorunu Demirci Efe konağı yeniden işlevlendirme projesi içinde geçerlidir. Zemin katta lobi mekânına altı adet oda açılmakta, birinci katta yatak odaları ile oturma salonu yan yana bulunmaktadır. Ancak yapının büyük bir alanını oluşturulan sofaların kullanımı kaçınılmazdır. Sofaların daraltılması ise sofa kurgusu üzerine kurulu geleneksel Türk Evi plan şemasının tamamen kaybolmasına neden olacağından gürültü problemine yalıtım bazlı kısmi çözüm aramak kaçınılmazdır.

\subsection{Ihtiyaç programı analizi}

Bugün Türkiye'de toplamda yaklaşık 500 butik otel bulunmaktadır ve bu sayı yeni yatırımlarla hızla artmaktadır. Yeni turizm tesisi türlerinin gelişmesine olanak sağlanması, mevcut turizm yatırım ve işletmelere ait tesislerin geliştirilmesi, turizm tesislerinin asgari niteliklerinin belirlenmesi, bu tesisler arasında standart birliğinin sağlanması ve kalitenin yükseltilmesi amacıyla hazırlanan "Turizm Tesislerinin Belgelendirilmesine ve Niteliklerine iliş̧in Yönetmelik" uyarınca butik oteller madde 43'de şu şekilde tanımlanmaktadır. Butik oteller, yapısal özelliği, mimari tasarımı, tefriş, dekorasyon ve kullanılan malzemesi yönünden özgünlük arz eden, işletme ve servis yönünden üstün standart ve yüksek kalitede, deneyimli veya konusunda eğitimli personel ile kişiye özel hizmet verilen ve aşağıda belirtilen nitelikleri taşıyan en az on odalı otellerdir. Modern, reprodüksiyon, antika gibi özelliği olan mobilya ve malzemeler ile tefriş ve dekorasyon, beş yıldızlı otel odaları için belirlenen nitelikleri taşıyan konforlu odalar, kapasiteye yeterli kabul holü, kahvaltı salonu, oturma salonu, yatak sayısının \%25'i oranında oturma imkânı olan, lobiden ayrı düzenlenmiş oturma salonu, kahvaltı ofisi ve kahvaltı salonu veya alakart lokanta ve yönetim odası mekânlarının bulunması gerekir.

Yapılan incelemede Demirci Efe konağının sahip olduğu 10 oda, 2 depo, 1 hayat ve 2 büyük sofa mekânı ile butik otel yönetmeliğine göre otelde bulunması istenilen oda sayısı, oturma salonu, kahvaltı salonu, lobi, idare gibi ihtiyaç duyulan tüm mekânları sağlayabildiği görülmüştür. Bu doğrultuda çalışmada aşağıda detaylı biçimde anlatılan yeniden işlevlendirme projesi hazırlanmıştır.

\subsection{Yeniden işlevlendirme projesi}

Yeniden işlevlendirme projesi kapsamında yapının bodrum katı, alakart lokanta, mutfak, depo ve servis birimlerine ayrılmıştır. Yapının hayat olarak kullanılan üst katla (lobi-sofa) ahşap merdiven vasıtasıyla doğrudan bağlantı kuran bölümü 40 kişilik alakart lokanta olarak düzenlenmiştir. Bu mekânın doğrudan bahçeye ulaşma imkânı, güney cepheye, manzaraya ve bahçeye açılan konumu bu fonksiyonu desteklemektedir. Ayrıca yan yol ve bahçe kullanılarak ikincil bir giriş imkânı vardır. 


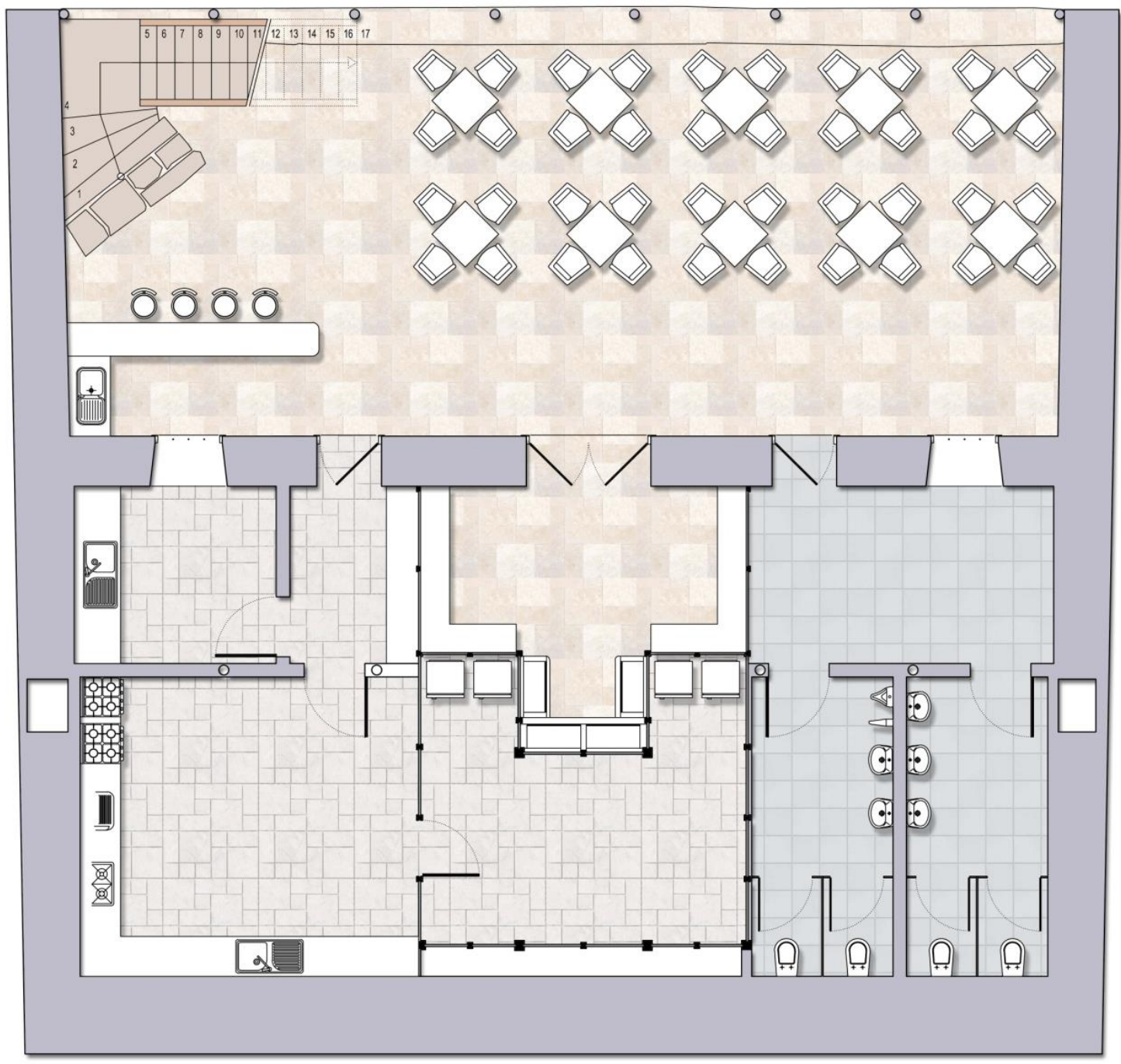

Şekil 10. Bodrum kat yeniden işlevlendirme projesi

Diğer taraftan bodrum katın diğer bölümleri geçmişte ahır-depo olarak kullanılan mekânlardır. Bu mekânlardan doğu cephedeki bölüm Şekil $10^{\prime}$ da görüldüğü biçimde mutfak ve servis ofisi olarak düzenlenmiş, ambar kısmı bu mekâna depo hizmeti verecek şekilde yeniden işlevlendirilmiştir. Ambarın mevcutta kapaklar bulunan ve hayattan ambara ulaşımı sağlayan giriş bölümü ise açık büfe sunum alanı olarak ayrılmıştır. Son bölüm wc ve lavabolar için kullanılmıştır. 


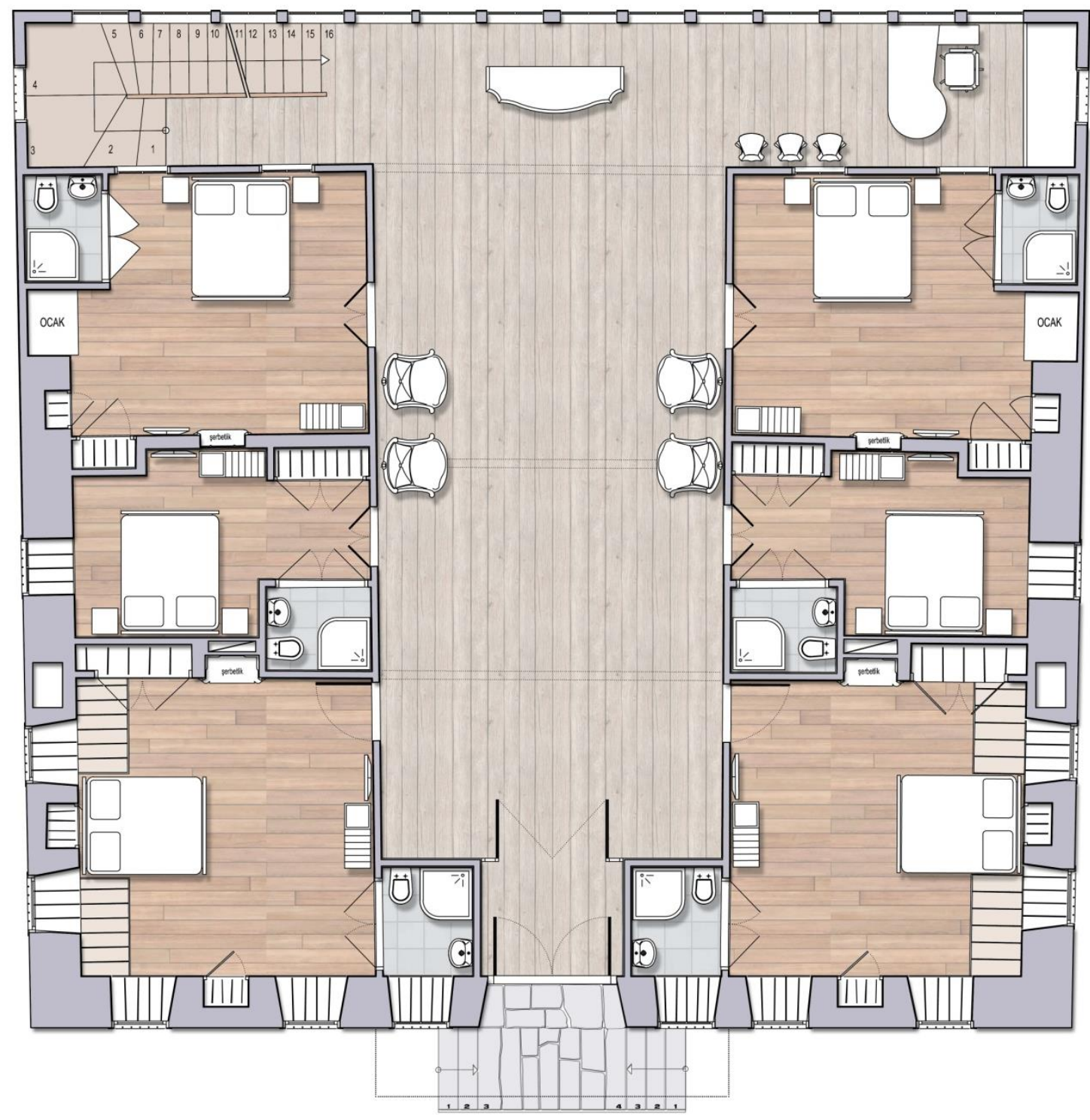

Şekil 11. Zemin kat yeniden işlevlendirme projesi

Yapının yol kotundan ulaşımı bulunan zemin katında sofa mekanı lobi ve resepsiyon olarak ayrılmıştır. Şekil 11'den detaylı biçimde incelenebileceği üzere T şeklindeki sofanın batı cephesindeki köşk kısmında küçük bir idari ofis tasarlanmıştır. Resepsiyon otel manzarasını arkasına alacak ve bir taraftan ana girişi karşılarken diğer taraftan yapının katlarına ulaşımı sağlayan ahşap merdivene yönlendirme yapacak biçimde konumlandırıımıştır. Zemin katta bulunan altı adet oda yatak odası olarak kullanılmış, yapısal olarak yapıya en az zarar verecek şekilde ve konumda minimal ölçülerde ıslak mekânlar eklenmiştir. Bu ıslak mekânların kapıları yapıdaki mevcut dolap kapaklarına uygun biçimde inşa edilerek, oda içerisine uyum sağlaması sağlanmıştır. Bunun dışında tüm ocak, sedir, dolap, şerbetlik gibi mimari elemanlar aslına uygun biçimde restore edilerek kullanılacaktır. 


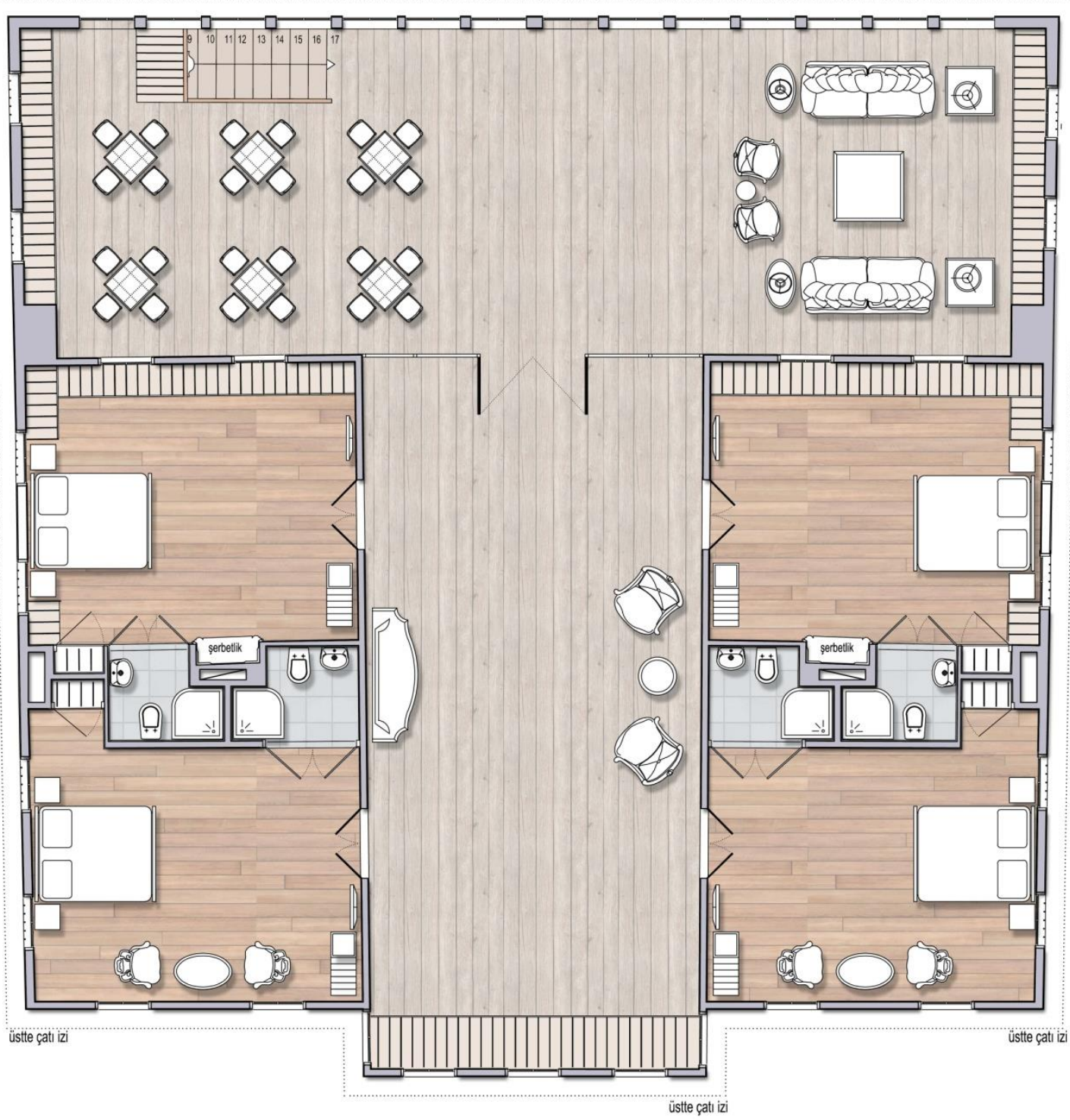

Şekil 12. 1. Kat yeniden işlevlendirme projesi

Şekil 12'de gösterildiği biçimde yapının 1. katında bulunan dört adet oda zemin kattakine benzer kriterler doğrultusunda yatak odasına dönüştürülmüştür. T şeklindeki sofanın manzaraya bakan bölümü diğer kısmından ayrılarak oturma salonu olanı olarak düzenlenecektir. Bu bölüme lobiden ulaşım imkânı bulunması güney cepheye bakan camekânlı konumu mekânın şekillenmesine etki etmiştir. Cam bir bölme ile ayrılan diğer sofa kısmından ise yatak odalarına ulaşılacaktır. Yapılan düzenlemeler sonucunda yapının en az müdahale ile butik otel yönetmeliğine uygun hale gelmesi amaçlanmıştır. Yapının plan şeması çok büyük ölçüde korunmuştur.

\section{Sonuç}

Türk evi olarak adlandırılabilen Osmanlı Dönemi geleneksel konutları, bölgelere göre; yaşam tarzı, malzeme, iklim gibi faktörlere göre değişiklik gösterse de tasarım öğeleri açısından ortak bir dile sahip olduğu konusu genel kabul görmektedir. Kültürel ve tarihsel değerlerimizi yansıtan bu eserlerin; korunması, onarılması ve yeniden kullanılması büyük önem taşımaktadır. Her ne kadar bu konutların özgün işleviyle yaşatılması birincil öncelik olsa da günümüz şartlarında bu yaklaşımı görmek mümkün olmamaktadır. íkinci alternatif ise bu konutların konaklama amaçı kullanılması olabilir. Pansiyon turizmi göz ardı edilmemekle birlikte, turizmde yeni bir kavram olarak ülkemizde yaygınlaşan butik otel; geleneksel Türk evinin otele dönüşümünde tasarım ve fonksiyon öğelerinin çakıştırılmasında uyum göstermektedir. Geleneksel Türk evinin butik otele dönüşümü sırasında ve sonrasında koruma, yerellik ve sürdürülebilirlik öğeleri değerlendirilmeli ve sağlanmalıdır. Yerel özelliklerin kullanılması, 
yerel özelliklerin ortaya çıkarılabilmesi ve sunulmasına imkân verirken, bu konu değerlendirilirken turizmin kitlesel yaklaşımından kaçınılmalıdır. Öyle ki bu yaklaşım Türk evinin orijinal değer ve özelliklerine zarar verebilir. Bu noktadan hareketle Isparta ili ve çevresi için tarihi ve mimari açıdan önem taşıyan İ̆decik Demirci Efe konağının butik otel fonksiyonu verilerek yaşatılması uygun bulunmuştur. Çalışma kapsamında barınma amaçlı kullanılmış olan Demirci Efe konağının, mimari biçimlenmesi, plan organizasyonu ve mekân örgütlenmesine uygun bir işlev seçimi ile turizm yapısına dönüştürme çalışması yapılmıştır. Bu dönüşüm sırasında kullanılan ölçütler ve analizler aşağıda Çizelge 5.1'de bir araya getirilmiştir.

Çizelge 5.1. Butik Otel dönüşüm analizi

\begin{tabular}{|c|c|c|}
\hline $\begin{array}{c}\text { İşlev } \\
\text { Ölçütleri }\end{array}$ & $\begin{array}{l}\text { Demirci Efe Konağı } \\
\text { Mevcut Durum Analizi }\end{array}$ & $\begin{array}{l}\text { Demirci Efe Konağı } \\
\text { Butik Otel Analizi }\end{array}$ \\
\hline 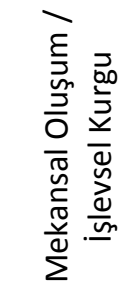 & $\begin{array}{l}\text { *Yapı iç sofalı plan tipindedir. } \\
\text { *Yapının mekansal oluşumu büyük } \\
\text { ölçüde korunmuştur. } \\
\text { *Sofa "T" planlıdır. }\end{array}$ & $\begin{array}{l}\text { *Yapı yüksek oranda butik otel işlev } \\
\text { kurgusunu desteklemektedir. } \\
\text { *Bodrum kat servis mekânlarının } \\
\text { çözümüne olanak sağlamaktadır. }\end{array}$ \\
\hline 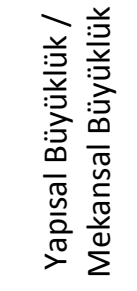 & $\begin{array}{l}\text { *Yapı } 260 \mathrm{~m}^{2} \text { taban alanına sahiptir. } \\
\text { *Bodrum üzeri iki kattan oluşur. } \\
\text { *12 adet oda, } 2 \text { adet sofa ve } 1 \text { adet } \\
\text { hanay, } 1 \text { adet ambar mekânı bulunur. }\end{array}$ & $\begin{array}{l}\text { *Toplam } 800 \text { m2 yapı büyüklüğü } \\
\text { mekân ihtiyaçlarını karşılayacak } \\
\text { niteliktedir. } \\
\text { *Zemin ve } 1 . \text { katta bulunan } 10 \text { oda } \\
\text { min. yatak odası talebine cevap } \\
\text { vermektedir. }\end{array}$ \\
\hline 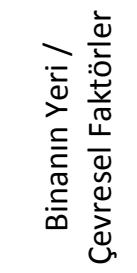 & $\begin{array}{l}\text { *Yapı Isparta - Burdur karayoluna } 5 \\
\text { km uzaklıkta köy merkezindedir. } \\
\text { *Güney cephede yer alan sofalar ova } \\
\text { manzarasına hâkim konumdadır. }\end{array}$ & $\begin{array}{l}\text { * Yapının yerleşim merkezinde } \\
\text { bulunması ulaşımı } \\
\text { kolaylaştırmaktadır. } \\
\text { *Ortak mekânların yer aldığı } \\
\text { sofalarda manzara kalitesi oldukça } \\
\text { yüksektir. }\end{array}$ \\
\hline 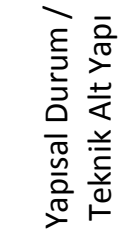 & $\begin{array}{l}\text { *Yapının ana taşıyıcı duvar ve } \\
\text { döşemeleri sağlam durumdadır. } \\
\text { *Dış cephe ve çatısı iklimsel koşullar } \\
\text { nedeniyle harap olmuştur. } \\
\text { *Yapıda elektrik ve su tesisatı vardır. }\end{array}$ & $\begin{array}{l}\text { *Yapı kapsamlı bir restorasyon } \\
\text { çalışması ardından uzun yıllar hizmet } \\
\text { verebilecek duruma gelecektir. } \\
\text { *Tüm tesisatlar yenilenecektir. }\end{array}$ \\
\hline 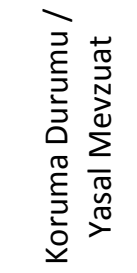 & $\begin{array}{l}\text { * Yapı Antalya Bölge Koruma Kurulu } \\
\text { tarafından koruma altına alınmış, sivil } \\
\text { mimarlık eseridir. }\end{array}$ & $\begin{array}{l}\text { *Konut fonksiyonunu kaybeden yapı } \\
\text { her geçen gün harap olmaktadır. } \\
\text { *Yeniden işlevlendirme yapının } \\
\text { korunumuna katkı sağlayacaktır. }\end{array}$ \\
\hline
\end{tabular}

Çalışmada ulaşılan elde edilen en önemli sonuç; önemli tarihsel olayların cereyan ettiği, yerel hafızada yer etmiş ve ayakta kalmayı başarmış bir mimari yapının sürdürülebilirliğinin sağlanmasıdır. Yerel çerçevede bilinen bir mimarinin daha geniş kitlelere turizm yoluyla tanıtılabilmesidir. Turizm olgusuna katılan turistin mekânda farklı deneyimler yapabilmesini sağlamaktır. Çalışmada incelenen yapı, içerisinde yaşandığı dönemin toplumsal olayları, bölgenin sosyo-kültürel ve sosyo-ekonomik yapısı, dönemin mimari özellikleri açısından önem taşımaktadır. Yapının turizm amaçlı kullanımına 
karar verilmesini de taşıdığı farklı boyutlardaki özellikleri gerekçelendirmektedir. Günümüzde kentsel ve kırsal alanda yok olmaya yüz tutmuş yapıların varlığını sürdürmesinde, korunmasında, koruma şekli ile yapı kullanımının organize edilmesi tercih edilmektedir. Bu çalışmada da koruma-kullanma dengesi ile bir yapının ayakta kalması, yaşatılması sağlanırken tercih edilen işlev nedeniyle bir bölgenin/yerelin kalkınması, cazibe merkezi haline gelmesi söz konusu olacaktır.

\section{Kaynaklar}

Altıner, A.T. ve Budak, C. (1997). Konak Kitabı, Tepe Yayınları, s.14-15, Ankara.

Canbulat, i. (2012). Gökçüler Konağı Restorasyonu ve Bir Butik Otel Olarak Işlevlendirilmesi, Ahşap Yapılarda Koruma ve Onarım Sempozyumu.

Demirci, D. (2009a). Demirci Mehmet Efe ve Isparta'nın İğdecik Köyü’ndeki Karargâh Konağı, Süleyman Demirel Üniversitesi Ilahiyat Fakültesi Dergisi Sayı: 22, s.125-144.

Demirci, D. (2009b). Geleneksel Isparta Evlerinde Giriş Düzenlemeleri, SDÜ Fen Edebiyat Fakültesi Sosyal Bilimler Dergisi, Sayı:20, ss.187-202.

De Planhol, X. (1958). De LaPlaine Pamphylienne Aux Lacs Pisidiens, Librairie Adrien-Maisonneuve, p.122, Paris.

Gürer, N. (2003). “Kırsal Geleneksel Konut Dokusunun Turizm Bağlamında Değerlendirilmesi, Cumalıkızık Örneği”, Gazi Üniversitesi Fen Bilimleri Enstitüsü, Yüksek lisans Tezi, s.238, Ankara.

Şaman Doğan, N. (2008). Isparta'da Selçuklu ve Beylikler Dönemi Mimarisi, Isparta Valiliği il Kültür ve Turizm Müdürlüğü Yayını, s.18, Isparta.

Uysal, Z. (2012). Ezine'nin Alemşah Köyünde Tarihi Bir Konak, Hacettepe Üniversitesi Edebiyat Fakültesi Dergisi, Cilt 29, Sayı 2, s.181-202.

Yüksel, i. (2009). Eski Türk Evi'nin Butik Otele Dönüşümünde Karşılaşılan Problemler, Sanatta Yeterlik Tezi.

URL-1. http://www.ispartagonen.gov.tr/

URL-2. http://isparta.igdecik.koyu.com.tr/ 